\title{
PENGARUH MOTIVASI DAN PENGETAHUAN TENTANG AKUNTAN PUBLIK TERHADAP MINAT MAHASISWA UNTUK MENGIKUTI PENDIDIKAN PROFESI AKUNTANSI \\ (Studi Kasus Mahasiswa Prodi Akuntansi Universitas Riau Kepulauan)
}

\section{THE EFFECT OF MOTIVATION AND KNOWLEDGE ABOUT PUBLIC ACCOUNTANT TOWARDS STUDENT INTEREST TO FOLLOW THE ACCOUNTING PROFESSIONAL EDUCATION (Case Study of Accounting Study Program Students at Riau Islands University)}

\author{
Sri Mulyati ${ }^{1}$ \\ ${ }^{1}$ (Akuntansi, Ekonomi, Universitas Riau Kepulauan, Indonesia) \\ ${ }^{1}$ sri@fekon.unrika.ac.id
}

\begin{abstract}
Abstrak
Penelitian ini bertujuan untuk mengetahui pengaruh motivasi dan pengetahuan akuntan publik terhadap minat mahasiswa akuntansi universitas pulau riau batam untuk mengikuti pendidikan profesi akuntansi. Menggunakan studi populasi atau studi sensus sampel yang digunakan sebanyak 69 responden. Data diperoleh dengan mengumpulkan data primer dalam bentuk kuesioner. Analisis data dalam penelitian ini adalah model regresi linier berganda yang diolah dengan menggunakan perangkat lunak SPSS versi 21. Hasil yang diperoleh dengan perhitungan telah dilakukan, untuk variabel motivasi uji t untuk $(-3,223)$, sedangkan $t$ tabel untuk $(1,668)$ ( $t$ uji $<t$ tabel) pada taraf signifikansi 0,002, ini menunjukkan bahwa motivasi tidak berpengaruh signifikan terhadap minat siswa untuk mengikuti pendidikan profesi akuntansi dan pengetahuan akuntan publik dari uji t pada $(3,322)$ sedangkan $t$ tabel $(1,668)$ (uji $t>t$ tabel) pada taraf signifikansi 0,001 berarti pengetahuan akuntan publik berpengaruh signifikan terhadap minat mahasiswa akuntansi universitas riau batam untuk mengikuti pendidikan profesi akuntansi. Motivasi dan pengetahuan akuntan pubis memiliki pengaruh positif signifikan pengaruh terhadap minat mahasiswa akuntansi universitas riau batam pulau untuk mengikuti pendidikan profesi akuntansi dengan nilai F-test 9,797, sedangkan Ftabel 3,140 (F-tes $t>$ F-tabel) dengan tingkat signifikan 0,000.
\end{abstract}

Kata Kunci ; motivasi, pengetahuan akuntan publik, minat mengikuti pendidikan profesi akuntansi

\begin{abstract}
This study aims to determine the effect of motivation and knowledge of public accountans on the interest of university accounting students riau batam island to follow the accounting profession education. Using a population study or sample census study used counted 69 respondents. Data obtained by collecting primary data in the form of questionnaire. Data analysis in this research is multiple linear regression model that is processed by using software SPSS version 21.The results obtained by calculation have been done, for motivation variable of t test for (-3.223), while t table for ( 1.668) ( $t$ test $<t$ table) at a significance level of 0,002, this show that motivation does not have significant effect on the interest of student to follow accounting profession education and knowledge of pubic accountant of t test at (3.322) while the t table (1.668) ( $t$ test $>t$ table) at a
\end{abstract}


significance level of 0,001 mean the knowledge of pubic accountant has a significant influence on the interest of university accounting students riau batam island to follow the accounting profession education.Motivation and knowledge of pubic accountant have a significant positive influence on the interest of university accounting students riau batam island to follow the accounting profession education with F-test value of 9.797, while the F-table 3.140 (F-test $>F$-table) with a significant level of 0.000 .

Keywords ; motivation, knowledge of public accountan, interest to follow accounting profession education

\section{Pendahuluan \\ Latar belakang}

Perkembangan zaman yang begitu

pesat mengakibatkan semakin terbukanya akuntan asing yang berpraktik di Indonesia. Melihat kondisi ini apakah saat ini akuntan Indonesia siap untuk menghadapi serbuan akuntan asing yang masuk ke Indonesia. Menanggapi tantangan tersebut, Dewan Pengurus Nasional IAI (Ikatan Akuntan Indonesia) Yusuf Halim (2012) menilai ada indikasi ketidaksiapan para akuntan Indonesia.

Untuk mempersiapkan kedatangan akuntan asing di Indonesia maka akuntan perlu meningkatkan kualitas agar tidak kalah bersaing dengan akuntan asing. Mahasiswa lulusan akuntansi dapat melanjutkan Pendidikan Profesi Akuntansi agar berkualitas di bidang akuntansi semakin meningkat dan dapat bersaing di era global. Mereka yang telah menempuh Pendidikan Profesi Akuntansi akan semakin berpeluang untuk berkarir sebagai auditor pemerintahan, auditor internal, akuntan sector public, akuntan manajemen, akuntan pendidik, akuntan perpajakan, akuntan keuangan maupun akuntan system informasi.

Motivasi berperan sentral sebagai sesuatu yang menyebakan, menyalurkan dan mendukung perilaku manusia, supaya mau bekerja giat dan antusias mencapai hasil yang optimal. Motivasi banyak dikaitkan dengan timbulnya minat. Minat adalah sesuatu yang pribadi dan berhubungan erat dengan sikap.
Akuntan publik adalah akuntan yang telah memperoleh izin dari menteri keuangan untuk memberikan jasa akuntan public. Ketentuan mengenai akuntan public di Indonesia UU No.5 tahun 2011 tentang Akuntan Publik dan Peraturan Menteri Keuangan Nomor 443/KMK.01/2011 tentang Penetapan Institut Akuntan Publik Indonesia sebagai Asosiasi Akuntan Publik Indonesia.

Penulis memiliki beberapa referensi penelitian terdahulu yang berkaitan dengan variabel motivasi, variabel pengetahuan dan minat. Kusumasturi (2013) meneliti Pengaruh Motivasi dan Pengetahuan UU No.5 TAHUN 2011 tentang Akuntan Publik terhadap minat mahasiswa Akuntansi Mengikuti Pendidikan Profesi Akuntansi (PPAK). Hasil penelitian tersebut menunjukan bahwa pengaruh Motivasi Karir, Motivasi Kualitas, MotivasI Ekonomi dan pengetahuan UU No.5 tahun 2011 tentang Akuntan Publik berpengaruh terhadap minat mahasiswa untuk mengikuti PPAK.

Pada penelitian Husin (2015) meneliti pengaruh motivasi kualitas dan motivasi ekonomi terhadap minat mahasiswa mengikuti Pendidikan Profesi Akuntansi (PPAK) dengan kepribadian individu sebagai variabel moderating. Hasil penelitian tersebut menunjukan bahwa motivasi kualitas dan motivasi ekonomi tidak berpengaruh signifikan terhadap minat mahasiswa untuk mengikuti PPAK.

Dari uraian permasalahan di atas penulis tertarik untuk melakukan penelitian 
dengan judul "Pengaruh Motivasi Dan Pengetahuan Tentang Akuntan Publik Terhadap Minat Mahasiswa Untuk Mengikuti Pendidikan Profesi Akuntansi (Studi Kasus Mahasiswa Prodi Akuntansi Universitas Riau Kepulauan Batam)".

\section{Batasan Masalah Penelitian}

Pembatasan masalah tersebut dilakukan agar pembahasan tidak mengalami perluasan dan penyimpangan dari variabel yang telah diuraikan penulis dalam latar belakang. Dalam penelitian ini lingkup yang akan diteliti dibatasi pada masalah motivasi dan pengetahuan tentang Akuntan Publik kaitannya dengan minat mahasiswa akuntansi mengikuti Pendidikan Profesi Akuntansi.

Mengenai variabel motivasi dalam penelitian ini, penulis membatasi ruang lingkup dengan menjadikan motivasi kualitas, dan motivasi ekonomi sebagai indikator pada variabel motivasi. Sedangkan Pengetahuan tentang Akuntan Publik yang dimaksud dalam penelitian ini adalah segala sesuatu yang diketahui mahasiswa akuntansi tentang akuntan publik, diantaranya syaratsyarat menjadi Akuntan Publik dan fungsi Akuntan Publik. Mengenai permasalahan pada variabel minat mahasiswa, penulis hanya meneliti tentang bagaimana minat yang dimiliki Mahasiswa Program Studi Akuntansi Unrika angkatan 2014-2015 untuk mengikuti Pendidikan Profesi Akuntansi.

\section{Perumusan Masalah}

Berdasarkan fenomena-fenomena dan latar belakang diatas, dapat disusun perumusan masalah sebagai berikut :

1. Bagaimana pengaruh Motivasi terhadap Minat Mahasiswa Prodi Akuntansi Universitas Riau Kepulauan Batam untuk mengikuti Pendidikan Profesi Akuntansi?

2. Bagaimana pengaruh Pengetahuan Tentang Akuntan Publik terhadap Minat Mahasiswa Prodi Akuntansi Universitas Riau Kepulauan Batam untuk mengikuti Pendidikan Profesi Akuntansi?

3. Bagaimana pengaruh Motivasi dan Pengetahuan Tentang Akuntan Publik terhadap Minat Mahasiswa Prodi Akuntansi Universitas Riau Kepulauan Batam untuk mengikuti Pendidikan Profesi Akuntansi.

\section{Tujuan Penelitian}

Berdasarkan uraian pada rumusan masalah diatas, maka tujuan penelitian ini adalah :

1. Untuk mengetahui pengaruh Motivasi terhadap Minat Mahasiswa Prodi Akuntansi Universitas Riau Kepulauan Batam untuk mengikuti Pendidikan Profesi Akuntansi.

2. Untuk mengetahui pengaruh Pengetahuan Akuntansi terhadap Minat Mahasiswa Prodi Akuntansi Universitas Riau Kepulauan Batam untuk mengikuti Pendidikan Profesi Akuntansi.

3. Untuk mengetahui pengaruh Motivasi dan Pengetahuan Akuntansi terhadap Minat Mahasiswa Prodi Akuntansi Universitas Riau Kepulauan Batam untuk mengikuti Pendidikan Profesi Akuntansi.

\section{Manfaat Penelitian}

Berdasarkan tujuan penelitian diatas, berikut ini ada beberapa manfaat bagi penelitian bagi beberapa pihak, antara lain:

1. Manfaat Teoritis

Hasil dari penelitian ini menambah bukti empiris mengenai faktor-faktor yang mempengaruhi minat mahasiswa Akuntansi untuk mengikuti Pendidikan Profesi 
Akuntansi (PPAK) sehingga Teori Pendidikan Akuntansi semakin berkembang.

\section{Manfaat Praktis}

Hasil dari penelitian ini memberikan informasi dan referensi bagi institusi pendidikan tentang faktor-faktor yang mempengaruhi minat mahasiswa Akuntansi untuk mengikuti Pendidikan Profesi Akuntansi (PPAK). Sehingga dapat digunakan dalam pengambilan keputusan.

3. Manfaat Bagi Peneliti dan Akademisi Dengan adanya penelitian ini diharapkan dapat menambah pengetahuan, baik bagi peneliti, maupun lembaga pendidikan, dan untuk menambah kepustakaan yang ada khususnya dibidang Akuntansi Keprilakuan. Penelitian ini diharapkan juga bisa memberikan pengetahuan mengenai lingkungan kerja Akuntan.

\section{TINJAUAN PUSTAKA Motivasi}

Sardiman (2011) mengemukakan bahwa motivasi merupakan sesuatu yang kompleks. Motivasi akan menyebabkan terjadinya suatu perubahan energi yang ada pada diri manusia, sehingga akan berhubungan dengan persoalan gejala kejiwaan, perasaan dan juga emosi, untuk kemudian bertindak atau melakukan sesuatu. Semua ini didorong karena adanya tujuan, kebutuhan atau keinginan. Motivasi mempunyai pengertian yang hampir sama dengan pengertian dari motif. Menurut Purwanto (2007), motif menunjukan suatu dorongan yang timbul dari dalam diri seseorang yang menyebabkan orangtersebut berkeinginan untuk bertindak melakukan sesuatu.

\section{Pengetahuan tentang akuntan public}

Akuntan publik adalah akuntan yang telah memperoleh izin dari menteri keuangan untuk memberikan jasa akuntan public. Ketentuan mengenai akuntan public di Indonesia UU No.5 tahun 2011 tentang Akuntan Publik dan Peraturan Menteri Keuangan Nomor 443/KMK.01/2011 tentang Penetapan Institut Akuntan Publik Indonesia sebagai Asosiasi Akuntan Publik Indonesia.

\section{Minat}

Slameto (2010) minat merupakan suatu rasa suka atau terikat pada suatu aktivitas tanpa ada paksaan dari pihak manapun.Menurut Kamus Besar Bahasa Indonesia, minat dapat diartikan sebagai suatu perhatian, kesukaan, kecenderungan hati pada sesuatu yang diinginkan.

Menurut Kamus Besar Bahasa Indonesia,minat dapat diartikan sebagai suatu perhatian, kesukaan,dan kecenderungan hati pada sesuatu yang diinginkan.Berdasarkan pengertian tentang minat diatas, dapat disimpulkan bahwa minat adalah suatu perasaan ketertarikan atau rasa kencerungan dalam hati manusia terhadap suatu hal dalam diri orang tersebut yang timbul akibat dari setelah melihat, mengamati dan membandingkan serta mempertimbangkan dengan kebutuhan yang diinginkannya tanpa adanya paksaan dari luar diri orang tersebut.

\section{Pendidikan profesi akuntansi}

Menurut International federation of accountan dalam Ellya Benny dan Yuskar (2006) yang dimaksud dengan profesi akuntan adalah semua bidang pekerjaan yang mempergunakan keahlian dibidang akuntansi. Keahlian tersebut mencakup bidang akuntan public, akuntan internal yang bekerja pada perusahaan, akuntan yang bekerja di pemerintah, dan akuntan sebagai pendidik. .

Pendidikan Profesi Akuntansi (PPAK) merupakan pendidikan yang diselenggarakan setelah menempuh 
pendidikan strata satu ekonomi jurusan Akuntansi dengan tujuan untuk mendapatkan gelar Akuntan (Ak). Hal ini sesuai dengan isi SK Mendiknas No.179/U/2011.

\section{Penelitian terdahulu}

1. Yuneriya (2015)Pengaruh Motivasi dan Persepsi lama Pendidikan terhadap Minat Mahasiswa Akuntansi untuk Mengikuti Pendidikan Profesi Akuntansi.

2. Teguh hadi prasetyo (2014)Pengaruh Motivasi, Persepsi biaya Penidikan dan Persepsi masa studi terhadap minat Mahasiswa Prodi Akuntansi UNY untuk mengikuti Pendidikan Profesi Akuntansi.

3. Kusumastuti(2013) Pengaruh Motivasi dan Pengetahuan UU No. 5 tahun 2011 tentang Akuntan Publik terhadap Minat Mahasiswa Mengikuti Pendidikan Profesi Akuntansi (PPAK)

4. Husin (2015) Pengaruh Motivasi Kualitas dan Motivasi Ekonomi TerhadaMinat Mahasiswa untuk Mengikuti Pendidikan Profesi Akuntansi (PPAK) dengan Kepribadian Individu Sebagai Variabel Moderating.

\section{Kerangka Pemikiran}

Berdasarkan uraian di atas, hubungan antara berbagai variabel yang menjadi obyek penelitian dapat digambarkan dengan kerangka pemikiran sebagai berikut

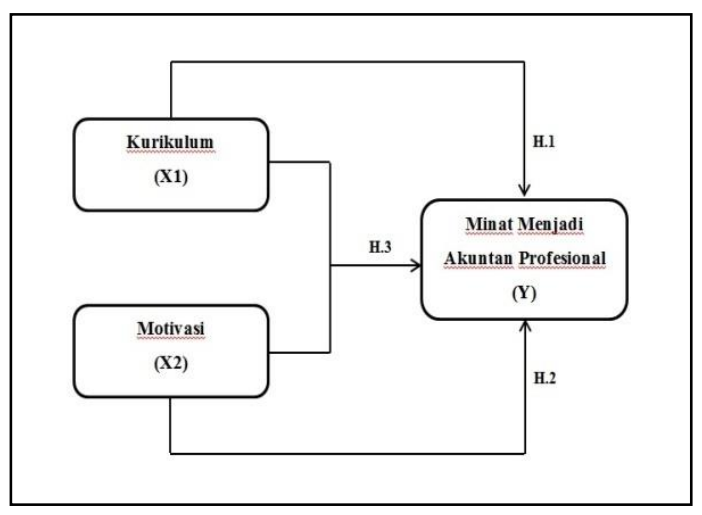

\section{Hipotesis Penelitian}

1. $\mathrm{H}_{1}$ :Motivasi berpengaruh signifikan terhadap Minat Mahasiswa Prodi Akuntansi Universitas Riau Kepulauan untuk mengikuti Pendidikan Profesi Akuntansi.

2. $\mathrm{H}_{2}$ :Pengetahuan Tentang Akuntan Publik berpengaruh signifikan terhadap Minat Mahasiswa Prodi Akuntansi Universitas Riau Kepulauan untuk mengikuti Pendidikan Profesi Akuntansi.

3. $\mathrm{H}_{3}$ :Motivasi dan Pengetahuan tentang Akuntan Publik berpengaruh signifikan terhadap Minat Mahasiswa Prodi Akuntansi Universitas Riau Kepulauan untuk mengikuti Pendidikan Profesi Akuntansi.

\section{Metodologi penelitian Subjek dan Objek Penelitian}

Yang menjadi subjek dalam Penelitian ini adalah Mahasiswa Prodi Akuntansi Fakultas Ekonomi, Universitas Riau Kepulauan, jalan Batu Aji Baru Kota Batam angkatan 2014 dan 2015 yang berjumlah 224 orang. 
Objek dalam penelitian ini adalah Pengaruh Motivasi dan Pengetahuan tentang Akuntan Publik terhadap Minat Mahasiswa Akuntansi untuk mengikuti Pendidikan Profesi Akuntansi (PPAK).

\section{Teknik Pengambilan Populasi dan Sampel Populasi}

Populasi adalah wilayah generalisasi yang terdiri atas obyek atau subyek yang mempunyai kualitas dan karateristik tertentu yang ditetapkan oleh peneliti untuk dipelajari dan kemudian ditarik kesimpulannya, Sugiyono (2010). Populasi yang digunakan dalam penelitian ini adalah Mahasiswa Prodi Akuntansi Universitas Riau Kepulauan Batam semester 5 dan 7 yang berjumlah 224 orang (menurut data bagian administrasi dan akademik kemahasiswaan Fakultas Ekonomi Universitas Riau Kepulauan Tahun Akademik 2018/2019)

Populasi yang ada dalam penelitian ini adalah sebagai berikut :

Mahasiswa Semester V:102 Mahasiswa

Mahasiswa Semester VII: 122 Mahasiswa

Total populasi : 224 Mahasiswa

\section{Sampel}

Sampel adalah bagian dari jumlah dan karakteristik yang dimiliki oleh populasi tersebut, Sugiyono (2010). Bila populasi besar dan peneliti tidak mungkin mempelajari semua yang ada pada populasi, misalnya keterbatasan dana, tenaga, dan waktu, maka peneliti dapat menggunakan sampel yang diambil dari populasi itu.

Sesuai dengan penelitian Teguh Hadiprasetyo (2014), teknik pengambilan sampel pada penelitian ini menggunakan proportionate stratified random sampling. Pada penelitian ini jumlah sampel ditentukan dengan menggunakan rumus Slovin dalam Hamta (2015) sebagai berikut.

$$
n=\frac{\mathrm{N}}{N \cdot d^{2}+1}
$$

Keterangan:

$\mathrm{n}=$ Jumlah Sampel

$\mathrm{N}=$ Jumlah Populasi (224 Mahasiswa)

$\mathrm{d}^{2}=$ Presisi (ditetapkan 10\%)

Sampel pada penelitian ini adalah sebagai berikut:

$$
\begin{aligned}
n & =\frac{\mathrm{N}}{N \cdot d^{2}+1} \\
n & =\frac{224}{224 \cdot 0,1^{2}+1} \\
n=69.236 & \approx 69
\end{aligned}
$$

Sedangkan proporsi sampel pada masingmasing angkatan adalah:

Mahasiswa Semester V : $\quad n=$

$\frac{102}{224} \times 69=31$ Mahasiswa

Mahasiswa Semester VII : $n=$

$\frac{122}{224} \times 69=38$ Mahasiswa

\section{Jenis Penelitian}

Penelitian dilakukan dengan pendekatan kuantitatif. Metode penelitian kuantitatif dapat diartikan sebagai metode penelitian yang berlandaskan pada filsafat positivism, digunakan untuk meneliti pada populasi atau sampel tertentu. Teknik pengambilan sampel pada umumnya dilakukan secara random atau acak. Pengumpulan data menggunakan instrument penelitian, analisis data bersifat kuantitatif / statistic dengan tujuan untuk menguji hipotesis yang telah ditetapkan (Sugiyono, 2010)

\section{Jenis Data Penelitian}

Dalam penelitian ini menggunakan data sebagai berikut :

\section{Data Primer}

Data primer yaitu data yang diperoleh secara langsung dari objek penelitian dengan cara melakukan observasi, 
mengadakan penelitian dan pencatatan secara langsung terhadap objek penelitian.

\section{Data Skunder}

Data skunder merupakan data yang diperoleh dan dikumpulkan oleh peneliti dari berbagai sumber yang telah ada dan berguna sebagai pendukung dari data primer.

\section{Teknik Pengumpulan Data}

Teknik pengumpulan data merupakan cara yang dilakukan peneliti untuk mengungkap atau menjaring informasi kuantitatif dari responden sesuai ruang lingkup penelitian (Sujarweni, 2014).

Berikut ini beberapa teknik pengumpulan data yang digunakan penulis dalam melakukan penelitian yang diadaptasi dari buku asmani (2011) dalam Sujarweni (2014) adalah sebagai berikut:

\section{Observasi}

Observasi adalah pengamatan dan pencatatan secara sistematik terhadap gejala yang tampak pada objek penelitian.

\section{Studi Pustaka}

$\begin{array}{cll}\text { Menurut } & \text { M.Nazir dalam bukunya } \\ \text { yang } & \text { berjudul } & \text { "Metode }\end{array}$ Penelitian"mengemukakan bahwa yang dimaksud dengan Studi kepustakaan adalah teknik pengumpulan data dengan mengadakan studi penelaahan terhadap buku-buku, litertur-literatur, catatancatatan, dan laporan-laporan yang ada hubungannya dengan masalah yang akan dipecahkan.

\section{Penulusuran Online}

Penelusuran online dilakukan dengan tata cara dan melalui media online seperti website dengan sumber yang terpercaya dan akurat, sehingga memungkinkan peneliti untuk memanfaatkan data dan informasi berupa teori yang mendukung permasalahan pada penelitian dan tentunya dapat dipertanggung jawabkan kebenarannya.

\section{Kuisioner atau Angket}

Menurut Sugiyono (2010) kuisioner atau angket merupakan teknik pengumpulan data yang dilakukan dengan cara memberikan seperangkat pertanyaan atau pernyataan tertulis kepada responden untuk memperoleh data.Penelitian ini menggunakan data primer, data primer ini diperoleh melalui kuesioner yang langsung disebarkan kepada mahasiswa aktif program studi Akuntansi Universitas Riau Kepulauan angkatan 2014 dan 2015.

\section{Defenisi operasional}

Menurut Sugiyono (2010) variabel penelitian adalah suatu atribut atau sifat atau nilai dari orang, obyek atau kegiatan yang mempunyai variasi tertentu yang ditetapkan oleh peneliti untuk dipelajari dan ditarik kesimpulannya.

Desain Operasional Variabel

\begin{tabular}{|c|c|c|c|}
\hline $\begin{array}{c}\text { NAMA } \\
\text { VARIABEL }\end{array}$ & $\begin{array}{c}\text { KETERANG } \\
\text { AN }\end{array}$ & ITEM & $\begin{array}{l}\text { NOM } \\
\text { ER } \\
\text { ITEM } \\
\end{array}$ \\
\hline \multirow{5}{*}{$\begin{array}{l}\text { MOTIVASI }(\mathrm{X} \\
\text { 1) }\end{array}$} & & $\begin{array}{l}\text { Mendapatk } \\
\text { an } \\
\text { Pengetahua } \\
\mathrm{n} \\
\text { Akuntansi }\end{array}$ & 1,2 \\
\hline & & $\begin{array}{l}\text { Meningkat } \\
\text { kan } \\
\text { pengetahua } \\
\text { n diri }\end{array}$ & 3,4 \\
\hline & & $\begin{array}{l}\text { Penghargaa } \\
\text { n langsung }\end{array}$ & 5,6 , \\
\hline & & $\begin{array}{l}\text { Penghargaa } \\
\mathrm{n} \text { tidak } \\
\text { langsung }\end{array}$ & 7 \\
\hline & \multicolumn{2}{|c|}{$\begin{array}{c}\text { JUMLAH } \\
\text { PERTANYAAN }\end{array}$} & 7 \\
\hline \multirow{4}{*}{$\begin{array}{c}\text { PENGETAHU } \\
\text { AN } \\
\text { TENTANG } \\
\text { AKUNTAN } \\
\text { PUBLIK }\left(\mathrm{X}_{2}\right)\end{array}$} & & $\begin{array}{l}\text { Ketentuan } \\
\text { umum }\end{array}$ & 1 \\
\hline & & KAP & 3,4 \\
\hline & & $\begin{array}{l}\text { Perzinan } \\
\text { AP }\end{array}$ & 2,5 \\
\hline & & & \\
\hline
\end{tabular}




\begin{tabular}{|c|c|c|}
\hline & $\begin{array}{c}\text { JUMLAH } \\
\text { PERTANYAAN }\end{array}$ & 5 \\
\hline \multirow{4}{*}{$\begin{array}{c}\text { MINAT } \\
\text { MAHASISW } \\
\text { A } \\
\text { MENGIKUTI } \\
\text { PPAK(Y) }\end{array}$} & $\begin{array}{l}\text { Fungsi } \\
\text { PPAK }\end{array}$ & 1 \\
\hline & $\begin{array}{l}\text { Minat } \\
\text { mengikuti } \\
\text { PPAK }\end{array}$ & 5 \\
\hline & $\begin{array}{l}\text { Manfaat } \\
\text { mengikuti } \\
\text { PPAK }\end{array}$ & $2,3,4$ \\
\hline & $\begin{array}{c}\text { JUMLAH } \\
\text { PERTANYAAN }\end{array}$ & 5 \\
\hline
\end{tabular}

Teknik Analisis Data

\section{Uji Kualitas Data}

\section{Uji Validitas}

Uji Validitas digunakan untuk mengetahuiseberapa cermat suatu item (kuesioner) dalam mengukur objeknya. Menurut Sugiyono (2010) dalam Hamta (2015) jika $r$ hitung $>r$ tabel maka pertanyaan atau indikator tersebut dinyatakan valid.

\section{Uji Reliabilitas}

Uji Reliabilitas digunakan untuk mengetahui konsistensi alat ukur yang biasanya menggunakan kuesioner dengan maksud apakah alat ukur tersebut akan mendapatkan pengukuran yang tetap konsisten jika pengukuran diulang kembali. Menurut Ghozali dalam Hamta (2015) seluruh butir pertanyaan dinyatakan reliable apabila jika nilai cronbach alpha $>0,60$.

\section{Uji Asumsi Klasik}

\section{Uji Normalitas Data}

Untuk menguji kenormalan data dilakukan dengan serangkaian pengujian yang bertujuan untuk membantu peneliti dalam menemukan distribusi normal agar populasi dapat terwakili.(Priyatno, 2011).

\section{Uji Multikolinieritas}

Multikolineritas adalah keadaan dimana ada hubungan linear secara sempurna atau mendekati sempurna antara variabel independen dalam model regresi.Model regresi yang baik adalah regresi yang terbebas dari multikolineritas.(Priyatno, 2011).

\section{Uji Heteroskedastisitas}

Uji Heteroskedastisitas dengan menggunakan metode Gleyserjika hasil nilai probabilitasnya memiliki signifikansi $>$ nilai alpha nya 0,05 maka model tidak mengalami heteroskedastisitas (Agung Wibowo, 2012) dalam Hamta (2015).

\section{Analisis Deskriptif Statistik}

Metode analisis deskriptif merupakan metode yang menjelaskan suatu data yang telah dikumpulkan dan diringkas pada aspekaspek penting berkaitan dengan data tersebut. Biasanya meliputi gambaran atau mendeskriptifkan suatu data mean, median, modus, range, varian, frekuensi, nilai maksimum, nilai minimum, dan standar deviasi (Agung Wibowo, 2012) dalam Hamta (2015).

\section{Analisis Regresi Linear Berganda}

Analisis linear berganda adalah hubungan secara linear antara dua atau lebih variabel independent $\left(\mathrm{X}_{1 . .,} \mathrm{X}_{2 . .,} \mathrm{X}_{3 \ldots,}\right)$ dengan variabel dependen (Y).Dapat juga dikatakan sebagai analisis yang digunakan untuk mengetahui apakah dua variabel atau lebih mempunyai pengaruh (Sujarweni, 2014).

\section{Uji Koefisien Regresi Secara Parsial (Uji t)}

Uji t digunakan untuk mengetahui apakah secara parsial variabel kurikulumdan variabel motivasiberpengaruh secara signifikan terhadap minat mahasiswa akuntansi menjadi akuntan professional.Pengujianparsial pada penelitian ini menggunakan tingkat signifikanasi $95 \%(\mathrm{a}=0,05)$.

- $\mathrm{H}_{\mathrm{a}}$ diterima jika $\mathrm{t}_{\text {hitung }}<\mathrm{t}_{\text {tabel }}$ pada $\mathrm{a}=5 \%$

- $\mathrm{H}_{\mathrm{a}}$ diterima jika $\mathrm{F}_{\text {hitung }}<\mathrm{F}_{\text {tabel }}$ pada $\mathrm{a}=5 \%$ 


\section{Uji Koefisien Regresi Secara Bersama- sama (Uji F)}

Uji $F$ digunakan untuk mengetahui pengaruh secara bersama-sama atau simultan antara variabel independen terhadap variabel dependen.Nilai $F_{\text {hitungakan dibandingkan }}$ dengan nilai $F_{\text {tabel }}$ dan kriteria pengambilan keputusannya adalah:

- $\mathrm{H}_{\mathrm{a}}$ diterima jika $\mathrm{F}_{\text {hitung }}<\mathrm{F}_{\text {tabel }}$ pada $\mathrm{a}=5 \%$

- $\mathrm{H}_{\mathrm{a}}$ ditolak jika $\mathrm{F}_{\text {hitung }}>\mathrm{F}_{\text {tabel }}$ pada $\mathrm{a}=5 \%$

\section{Uji Koefisien Determinasi $\left(\mathbf{R}^{\mathbf{2}}\right)$}

MenurutSugiyono (2010) Koefisien determinasi ( $\mathrm{R}$ kuadrat) pada intinya mengukur seberapa jauh kemampuan model dalam menerangkan variable -variabel dependen.

\section{HASIL PENELITIAN}

Hasil Uji Parsial (Uji T)

Uji T dimaksudkan untuk mengetahui seberapa jauh pengaruh satu variabel independen (Motivasi dan Pengetahuan Tentang Akuntan Publik) secara individual dalam menerangkan variabel dependen (Minat Mahasiswa Prodi Akuntansi untuk mengikuti PPAK). penelitian ini menggunakan tingkat signifikanasi $95 \%(a=0,05)$.

- $\mathrm{H}_{\mathrm{a}}$ diterima jika $\mathrm{t}_{\text {hitung }}<\mathrm{t}_{\text {tabel }}$ pada $\mathrm{a}=5 \%$

Coefficients $^{\mathrm{a}}$

\begin{tabular}{|c|c|c|c|c|c|}
\hline \multirow[t]{2}{*}{ Model } & \multicolumn{2}{|c|}{$\begin{array}{l}\text { Unstandardized } \\
\text { Coefficients }\end{array}$} & \multirow{2}{*}{\begin{tabular}{|c}
$\begin{array}{c}\text { Standardi } \\
\text { zed } \\
\text { Coefficien } \\
\text { ts }\end{array}$ \\
Beta
\end{tabular}} & \multirow[t]{2}{*}{$\mathrm{t}$} & \multirow[t]{2}{*}{ Sig. } \\
\hline & B & $\begin{array}{l}\text { Std. } \\
\text { Error }\end{array}$ & & & \\
\hline (Constant) & 19.790 & 2.439 & & 8.113 & .000 \\
\hline Motivasi_X & -.183 & .057 & -.350 & -3.223 & .002 \\
\hline $\begin{array}{l}\text { Pengetahuan } \\
\text { X2 }\end{array}$ & .314 & .095 & .361 & 3.322 & .001 \\
\hline
\end{tabular}

a. Dependent Variable: Minat_Y

- $\mathrm{H}_{\mathrm{a}}$ diterima jika $\mathrm{F}_{\text {hitung }}<\mathrm{F}_{\text {tabel }}$ pada $\mathrm{a}=5 \%$ Sumber : Lampiran Output Pengolahan Data pada SPSS 23, 2018 Hasil Uji Simultan (Uji F)
Uji $F$ digunakan untuk mengetahui pengaruh secara bersama-sama atau simultan antara variabel independen terhadap variabel dependen.Nilai F Fitungakan dibandingkan dengan nilai $F_{\text {tabel }}$ dan kriteria pengambilan keputusannya adalah:

- $\mathrm{H}_{\mathrm{a}}$ diterima jika $\mathrm{F}_{\text {hitung }}<\mathrm{F}_{\text {tabel }}$ pada $\mathrm{a}=5 \%$

- $\mathrm{H}_{\mathrm{a}}$ ditolak jika $\mathrm{F}$ hitung $>\mathrm{F}_{\text {tabel }}$ pada $\mathrm{a}=5 \%$

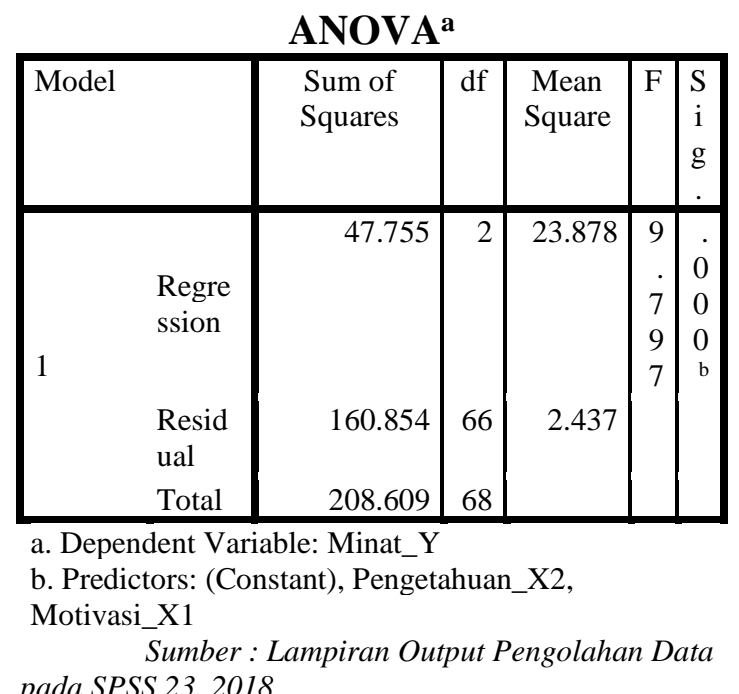

\section{Uji Koefisien Determinasi $\left(\mathbf{R}^{\mathbf{2}}\right)$}

Uji koefisien determinasi $\left(\mathrm{R}^{2}\right)$ pada intinya mengukur seberapa jauh kemampuan model dalam menerengkan variasi variabel dependen. Nilai koefisien determinasi adalah antara 0 (nol) sampai 1 (satu). Jika nilai $R$ Square bernilai besar (mendeteksi 1) berarti variabel bebas dapat memberikan hampir semua informasi yang dibutuhkan untuk memprediksi variabel dependen (Sugiyono, 2010).

\begin{tabular}{|c|c|c|c|c|}
\hline \multicolumn{5}{|c|}{ Model Summary } \\
\hline Model & $\mathrm{R}$ & R Square & $\begin{array}{l}\text { Adjust } \\
\text { ed R } \\
\text { Squar } \\
\text { e }\end{array}$ & $\begin{array}{l}\text { Std. Error of the } \\
\text { Estimate }\end{array}$ \\
\hline 1 & $.478^{a}$ & .229 & .206 & 1.561 \\
\hline
\end{tabular}

a. Predictors: (Constant), Pengetahuan_x2, Motivasi_x1 b. Dependent Variable: Minat_Y 
Sumber : Lampiran Output Pengolahan Data pada SPSS 23, 2018

\section{PEMBAHASAN HASIL PENELITIAN}

Penelitian ini bertujuan untuk mengetahui pengaruh Motivasi (X1) dan Pengetahuan Tentang akuntan Publik (X2) terhadap minat mahasiswa Prodi Akuntansi Universitas Riau Kepulauan mengikuti Pendidikan Profesi Akuntansi (Y). Berdasarkan hasil analisis, maka pembahasan akan dijelaskan sebagai berikut:

1. Pengaruh Motivasi terhadap Minat Mahasiswa Prodi Akuntansi UNRIKA Untuk Mengikuti Pendidikan Profesi Akuntansi

Berdasarkan hasil analisis data diketahui bahwa Motivasi berpengaruh positif namun tidak signifikan terhadap minat mahasiswa untuk menigikuti Pendidikan Profesi Akuntansi. Hasil uji hipotesis secara individu menunjukan bahwa Motivasi memiliki nilai t hitung 3,223 dengan t tabel sebesar 1,668 karena nilai $\mathrm{t}$ hitung $<\mathrm{t}$ tabel maka halmini membuktikan bahwa Motivasi tidak memiliki pengaruh yang signifikan terhadap minat mahasiswa ptosi akuntansi untuk mengkuti Pendidikan Profesi Akuntansi.

Hasil penelitian ini konsisten dengan hasil penelitian yang dilakukan oleh Husin (2015) yang menyatakan bahwa variabel Motivasi tidak berpengaruh positif dan signifikan terhadap minat mengikuti PPAK. Dalam hal ini, menurut Husin, seseorang yang memiliki Motivasi berarti orang tersebut memiliki kemauan dari dalam dirinya untuk terus maju dengan tujuannya. Semakin tinggi Motivasi yang dimiliki Mahasiswa maka Mahasiswa tersebut akan semakin berminat untuk mengikuti Pendidikan Ptofesi Akunatansi.

\section{Pengaruh Pengetahuan Tentang Akuntan Publik terhadap Minat}

Mahasiswa Prodi Akuntansi Untuk Mnengkikuti Pendidikan Profesi Akuntansi

Hasil penelitian mendukung hipotesis kedua bahwa variabel Pengetahuan Tentang Akuntan publik (X2) berpengaruh signifikan terhadap Minat Mahasiswa Prodi Akuntansi Universitas Riau Kepulauan untuk mengikuti PPAK (Y). Hal ini ditunjukkan oleh hasil analisis data diperoleh nilai thitung sebesar 3,322dengan tingkat signifikansi 0,001. Jadi diperoleh nilai thitung $3,322>1,668$ $t_{\text {tabel }}$ dengan signifikansi sebesar 0,001 < 0,05 . Nilai thitung tersebut lebih besar dari nilai $t_{\text {tabeldan }}$ nilai signifikansi tersebut lebih kecil dari 0,05, yang berarti $\mathrm{Ha}$ diterima dan $\mathrm{HO}$ ditolak. Maka dapat dinyatakan bahwa pengetahuan tentang akuntan publik berpengaruh secara positif signifikan terhadap variabel Minat Mahasiswa Prodi Akuntansi Universitas Riau Kepulauan untuk mengikuti pendidikan profesi akuntansi.

Hasil penelitian ini konsisten dengan hasil penelitian yang dilakukan oleh kusumastuti (2013) yang menyatakan bahwa variabel pengetahuan tentang Akuntan Publik mempengaruhi variabel Minat mengikuti pendidikan profesi Akuntansi. Dalam hal ini tidak hanya motivasi namun pengetahuan merupakan hal yang paling mendukung sehingga mempengaruhi minat seseorang untuk mengikuti pendidikan Profesi akuntansi .

\section{Pengaruh Motivasi dan Pengetahuan Tentang Akuntan Publik Untuk Mengikuti Pendidikan Profesi Akuntansi}

Betdasarkan hasil analisis data diketahui motivasi dan pengetahuan tentang akuntan publik berpengaruh possitif dan signifikan terhadap tingkat pemahaman akuntansi pada mahasiswa 
Prodi Akuntansi Universitas Riau Kepualauan. Dengan menggunakan uji F dapat diketahui apakah secara stimulan motivasi dan pengetahuan tentang akuntan publik berpengaruh secara signifikan terhadap minat mengikuti Pendidikan Profesi Akuntansi. Pengujian menggunakan tingkat signifikan 0,05.

Berdasarkan hasil uji $F$ memperlihatkan nilai $\mathrm{F}$ hitung sebesar 41,783 dengan nilai signifikansi sebesar 0,000. Jadi diperoleh nilai $F_{\text {hitung }}$ 9,797 > 3,14 $\mathrm{F}_{\text {tabel }}$ dengan signifikansi sebesar $0,000<0,05$. Nilai $F_{\text {hitung }}$ tersebut lebih besar dari nilai $F_{\text {tabel }}$ dan nilai signifikansi tersebut lebih kecil dari 0,05, yang berarti $\mathrm{Ha}$ diterima dan $\mathrm{HO}$ ditolak. Artinya secara bersama-sama motivasi dan Pengetahuan tentang akuntan public berpengaruh positif dan signifikan terhadap Minat Mahasiswa Prodi Akuntansi Universitas Riau Kepulauan untuk mengikuti Pendidikan Profesi Akuntansi.

\section{KESIMPULAN}

Berdasarkan hasil analisis data dan pembahasan hasil penelitian tentang pengaruh motivasi dan pengetahuan tentang akuntan publik terhadap minat Mahasiswa Akuntansi Universitas Riau Kepulauanuntuk mengikuti pendidikan profesi akuntansi maka dapat ditarik beberapa kesimpulan yaitu:

1 Motivasi tidak berpengaruh terhadap minat mahasiswa Akuntansi Universitas Riau Kepulauan untuk mengikuti pendidikan profesi akuntansi. Hal ini ditunjukan dengan nilai $\mathrm{t}$ hitung $-3,223<1,668 \mathrm{t}$ tabel dengan signifikansi sebesar $0,002<$ 0,05 .

2 Pengetahuan tentang akuntan public memiliki pengaruh positif yang signifikan terhadap minat mahasiswa akuntansi untuk mengikuti pendidikan profesi akuntansi .Karena nilai $\mathrm{t}$ hitung 3,322>1,,668 t tabel dengan signifikansi sebesar $0,001<$ 0,05 .

3 Motivasi dan pengetahuan tentang akuntan public memiliki pengaruh positif yang signifikan terhadap minat mahasiswa auntuk mengikuti pendidikan profesi akuntansi. Karena hasil $\mathrm{F}$ hitung 9,797> 3,14 $\mathrm{F}$ tabel dengan signifikansi sebesar $0,000<$ 0,05 .

\section{.Saran Penelitian}

Berdasarkan kesimpulan di atas, selanjutnya dapat diusulkan saran yang diharapkan akan bermanfaat berkaitan dengan prestasi mahasiswadi kampus, yaitu:

1. Referensi penelitian seperti jurnal dan penelitian terdahulu dengan menggunakan variabel pengetahuan tentang akuntan publik masih sangat jarang dan sulit untuk ditemukan. Maka dari itu, peneliti selanjutnya dapat memecahkan fenomena yang terjadi variabel pengetahuan tentang akuntan publik dengan menyandingkan dengan variabel penelitian lainnya agar di waktu yang akan datang dapat dibandingkan dengan hasil penelitian pada saat ini.

2. Motivasi dan pengetahuan tentang akuntan public memberikan sumbangan sebesar 22,9\% terhadap Minat Mahasiswa Prodi Akuntansi Universitas Riau Kepulauan untuk mengikuti pendidikan profesi akuntansi. Sedangkan sisanya sebesar $77,1 \%$ dijelaskan oleh faktor lain di luar penelitian ini. Oleh karena itu, bagi peneliti selanjutnya dapat menambah variabel pendukung lainnya. 
4 Mahasiswa Prodi Akuntansi Universitas Riau Kepulauan saat ini memiliki motivasi sedang dan tinggi. Dengan tingkat motivasi yang seperti ini perlu dipertahankan kedepannya agar sebagian besar bahkan semua mahasiswa Prodi Akuntansi memiliki Minat untuk mengikuti pendidikan profesi akuntansi.

5. Diharapkan untuk peneliti-peneliti yang akan datang untukdapat kembali melakukan pembuktian variabel ini dalam kasus yang sama dengan menambah variabel lainnya yang belum di uji pada penelitian ini agar menguatkan hasil penelitian.

\section{DAFTAR PUSTA}

Hamta, Firdaus. (2015). Metodologi Penelitian Akuntansi. Yogyakarta Deepublish.

Moh.Nazir, (2011). Metode Penellitian. Bogor : Ghalia Indonesia.

Priyono, (2016). Metode Penelitian Kuantitatif. Surabaya : Zifatama Publishing.

Sardiman A.M, (2011). Interaksi dan Motivasi Belajar Mengajar. Jakarta : PT RajaGrafindo Persada.

Satria, (2016). Teori Konsep Motivasi (Pengertian, Jenis, Faktor Dan Proses Motivasi Menurut Para Ahli)

http://www.materibelajar.id/2016/04/teori-

konsep-motivasi-pengertianjenis.html(diakses 15 november 2017)

Satria, (2016). Materi Pelayanan Publik : Tentang Definisi Kualitas Menurut Para Ahli (Teori Dan Konsep Kualitas Pada Pelayanan Publik)

http://www.belajarakuntansionline.com/tuga s-akuntan-publik-auditorindependen/(diakses 16 november 2017)
Sugiyono, (2010). Metode Penelitian Bisnis Kuantitatif Kualitatif, dan R\&D. Bandung: Alfabeta.

Teguh Hadi Prasetyo, (2014). Pengaruh Motivasi, Persepsi Biaya Pendidikan, dan Persepsi Masa Studi Terhadap Minat Mahasiswa Akuntansi UNY untuk Mengikuti Pendidikan Profesi Akuntansi. Skripsi : Prodi Pendidikan Akuntansi Universitas NegeriYogyakarta.

V. Wiratna Sujarweni, (2014). Metodologi Penelitian. Yogyakarta : PT. Pustaka Baru Press. 